\title{
The Diabetes-Cancer Link
}

\author{
Karen K. Collins, MS, RDN, CDN
}

Type 2 diabetes is associated with increased risks for several cancers, including colon, ${ }^{1}$ postmenopausal breast, ${ }^{2}$ pancreatic, ${ }^{3}$ liver, ${ }^{4}$ endometrial, ${ }^{5}$ and bladder ${ }^{6}$ cancers and non-Hodgkins lymphoma. ${ }^{7}$ Type 2 diabetes is also linked to a modest decrease in the risk for prostate cancer. ${ }^{8}$ However, diabetes does not reduce aggressive forms, and prostate cancer mortality rates are higher among men with diabetes., ${ }^{9,10}$ Overall, increased cancer mortality associated with diabetes reflects both increased cancer incidence and decreased survival among people with diabetes who develop cancer. ${ }^{11-13}$

Research is underway examining how antihyperglycemic medications may affect cancer risk and progression. Some evidence suggests that metformin may decrease risk, and researchers are exploring whether it might even play a role in the treatment of some cancers. ${ }^{14,15}$

\section{Mechanisms Linking Type 2 \\ Diabetes and Cancer}

Normal cells develop into malignant cancer cells through a complex process, including initiation (DNA damage from a carcinogen or reactive molecule), promotion (stimulation of initiated cells' growth), and progression (more aggressive growth with angiogenesis and metastasis). Most cancers develop over at least 10-20 years. Numerous factors, including some related to metabolic states in overweight, obesity, and type 2 diabetes, as well as dietary intake and physical activity, appear to promote or inhibit cancer development. ${ }^{16-18}$
Elevated insulin and related growth factors

In epidemiological studies, elevated levels of insulin or C-peptide (a biomarker of insulin production) predict increased risk for colorectal, postmenopausal breast, pancreatic, bladder, and endometrial cancers. ${ }^{14,19}$ Insulin binding to its receptor activates the metabolic pathway, which stimulates glucose uptake and glycogenesis and suppresses lipolysis and liver gluconeogenesis.

Although insulin resistance blocks signaling in the metabolic pathway, it does not inhibit activation of the cell-signaling pathway involving mitogen-activated protein kinase that promotes cell proliferation. Increased insulin production to overcome blockade of the metabolic pathway exaggerates activation of this mitogenic pathway. Some evidence suggests that cancer cells may be particularly affected by hyperinsulinemia because of an increased concentration of insulin receptors, often in a form that is particularly mitogenic. ${ }^{20,21}$

Insulin-like growth factor-1 (IGF-1) is a polypeptide synthesized by almost all cells, although primarily by the liver. Elevated insulin stimulates production of IGF-1 and decreases production of its binding proteins, thus increasing bioavailable IGF-1. Cell studies suggest that IGF-1 is even more potent than insulin in promoting cell proliferation and inhibiting apoptosis (self-destruction of abnormal cells). ${ }^{16,19,21}$ Human population studies link higher levels of IGF-1 with an increased risk for colorectal and estrogen receptor-positive breast 
cancer and possibly prostate and other cancers. ${ }^{14,19,22,23}$

\section{Estrogen and testosterone}

In postmenopausal women, body fat becomes the primary site of estrogen synthesis, and obesity is linked to elevated serum estrogen, increasing the risk for postmenopausal breast and endometrial cancers among women who do not use hormone replacement therapy. ${ }^{18}$ Hyperinsulinemia decreases liver production of sex hormone-binding globulin, which increases estrogen bioavailability. In women, hyperinsulinemia increases bioavailable testosterone, which is also linked to cancer risk. ${ }^{17}$

\section{Chronic inflammation}

Type 2 diabetes and obesity are both characterized by chronic low-grade inflammation, which increases production of free radicals that can disrupt insulin signaling and damage DNA. Ensuing genetic mutations can lead to cancer. ${ }^{20,24}$ Adipose cells produce a range of pro-inflammatory cytokines (cell-to-cell signaling proteins), including interleukin- 6 (IL-6) and tumor necrosis factor- $\alpha$ (TNF- $\alpha$ ).

IL- 6 and TNF- $\alpha$ trigger activation of signaling pathways that induce expression of genes promoting cell proliferation and angiogenesis and inhibiting apoptosis. Human studies link elevated levels of IL-6, TNF- $\alpha$, and C-reactive protein (a biomarker of inflammation) to greater risks for colorectal and possibly breast, prostate, lung, and other cancers, but research exhibits some inconsistencies. ${ }^{25,26}$

\section{Obesity and overweight}

Adipose tissue consists of adipocytes, as well as endothelial and immune cells. Cytokines such as TNF- $\alpha$ and IL- 6 that are released from adipose cells can promote inflammation and insulin resistance associated with cancer risk and progression.

Greater body fat, particularly with insulin resistance, tends to increase leptin production. Rising leptin levels further increase hyperinsulinemia, promote inflammation, and induce aromatase enzymes that raise estrogen production in postmenopausal women. In cell studies, leptin also directly promotes cell proliferation and angiogenesis and inhibits apoptosis..$^{27}$ Population studies link elevated leptin to increased incidence of colorectal, postmenopausal breast, and potentially other cancers. ${ }^{28}$

Obesity is associated with decreased production of adiponectin, another adipose-derived hormone. In vitro and in vivo studies demonstrate the insulin-sensitizing, tumor-inhibiting, anti-inflammatory effects of adiponectin. Reduced adiponectin may promote cancer development through increased insulin resistance and inflammation or through changes in cell signaling that increase cell proliferation and angiogenesis. ${ }^{21,28}$ Several prospective studies link decreased adiponectin to increased colon cancer and postmenopausal breast cancer, and limited data show links to other cancers. ${ }^{21}$

\section{Effects of hyperglycemia}

An unanswered question about the type 2 diabetes-cancer link involves the effect of blood glucose. Hyperglycemia increases production of free radicals and other reactive molecules, which could produce oxidative damage to DNA, leading to mutations in oncogenes and tumor suppressor genes. ${ }^{20}$ Research is unclear about whether higher circulating glucose particularly fuels malignant cell growth. ${ }^{17}$

Some studies link elevated A1C and other measures of hyperglycemia to increased risk of certain cancers, ${ }^{29-31}$ although they cannot show cause and effect. These studies often do not control for insulin levels or potential treatment-related confounders. A meta-analysis of intervention trials of people with type 2 diabetes showed no link between $\mathrm{A} 1 \mathrm{C}$ and cancer risk or cancer mortality. ${ }^{32}$ Because chronically elevated glucose levels are associated with insulin resistance and often with excess body fat, research is not yet clear about a direct impact of hyperglycemia on cancer risk. ${ }^{14,16,20}$ In animal studies, hyperglycemia without hyperinsulinemia does not lead to increased neoplastic growth, suggesting that insulin receptor acti- vation may be more important than hyperglycemia to tumor growth. ${ }^{17}$

\section{Integrating Cancer Risk Reduction} Into Diabetes Care

Because the diabetes-cancer connection is statistically significant and clinically important, "cancer screening and counseling on lifestyle changes should be part of preventive care in people with obesity and/or diabetes," according to a consensus statement from the American Association of Clinical Endocrinologists and the American College of Endocrinology. ${ }^{14}$ This proactive approach is also suggested for those who are overweight (BMI of 25 to $<30 \mathrm{~kg} / \mathrm{m}^{2}$ ) or with prediabetes because associated metabolic abnormalities are linked to cancer risk. ${ }^{17}$

Aim for a healthy level of body fat, especially at the waist Excess body fat is strongly linked to greater risks for several cancers, and the lowest cancer mortality rate is at the lower end of the normal $\mathrm{BMI}$ range. To reduce cancer risk, the American Institute for Cancer Research (AICR) and American Cancer Society (ACS) recommend that people should, "Be as lean as possible without becoming underweight." 18,33

For those who are overweight or obese, the American Diabetes Association (ADA) Standards of Medical Care in Diabetes recommends a $7 \%$ weight loss to reduce risk for diabetes and notes that even a loss of 2-8 kg (4.4-17.6 lb) may provide clinical benefits in those with type 2 diabetes. ${ }^{34}$ It is not yet clear how modest weight loss affects cancer risk. Observational cohort studies and controlled intervention trials using biomarkers of hyperinsulinemia, bioavailable estrogen and testosterone, and inflammation-the mechanisms through which excess body fat appears to increase cancer risk-suggest that weight loss of at least $10 \%$ may be most beneficial. ${ }^{35-37}$ Further research is needed to clarify appropriate targets.

Abdominal fat is particularly linked to insulin resistance and elevated levels of inflammatory cytokines, and greater waist circumference is directly linked to 
increased colon cancer risk. ${ }^{38}$ AICR recommends a waist circumference no larger than 37 inches in men and 31.5 inches in women. Further research is needed for ethnicityspecific standards. ${ }^{18}$

Strategies to recommend include:

- Reducing calorie density reduces calorie consumption. ${ }^{39,40}$ One of the most effective ways to accomplish this is to eat more nonstarchy vegetables while reducing portions of foods concentrated in calories. ${ }^{40,41}$

- An eating pattern low in calorie density can include modest amounts of foods high in calorie density, such as oils, nuts, and seeds, which add nutritional value. ${ }^{42}$

Focus eating around vegetables, fruits, whole grains, and beans A plant-focused eating pattern is linked to lower cancer risk. ${ }^{18,22}$ Plant foods supply dietary fiber, nutrients, and phytochemicals that seem to provide protection throughout the process of cancer development. In addition to reducing overall calorie density, vegetables and fruits provide fiber, nutrients vital for DNA production and antioxidant protection, and phytochemicals that may intervene throughout the cancer process, for example, activating expression of tumor suppressor genes. ${ }^{18,33}$

Dietary fiber has been convincingly linked to a lower risk for colorectal cancer, ${ }^{38}$ and metaanalysis has linked dietary fiber to a lower risk of breast cancer. ${ }^{43}$ Protection may stem from varied effects of different types of fiber, including decreased gut transit time and fermentation by gut bacteria to produce short-chain fatty acids that apparently promote normal colon cell differentiation and reduce inflammation. Yet, the reduced risk of colorectal cancer linked to whole grains likely comes from more than their fiber because whole grains are higher than refined grains in several potentially cancer-protective nutrients. Legumes are rich in dietary fiber that can be fermented in the colon, forming short-chain fatty acids. Whole grains and legumes provide polyphenol compounds that cell and animal studies suggest may deter cancer development.

Strategies to recommend include:

- A total of at least 2.5 cups of vegetables and fruits daily meets ACS and AICR recommendations.

AICR's recommendation refers to nonstarchy vegetables and fruits; potatoes and legumes do not count toward that goal.

- Vegetable and fruit targets should emphasize not only amount, but also variety, including choices rich in carotenoids and vitamin $\mathrm{C}$ and cruciferous and garlic-onionfamily vegetables.

- ACS and AICR recommend whole grains as the primary grain choice and advise minimizing refined grains.

- Dried beans and peas can replace all or part of the meat in some dishes.

\section{Limit red meat and avoid processed meat}

A meta-analysis shows a $17 \%$ increased risk for colorectal cancer per $100 \mathrm{~g}$ of red meat consumed per day. ${ }^{44}$ Choosing lean cuts is not enough to remove cancer risk; higher heme iron content apparently increases risk by promoting nitrosamine formation within the gut and through generation of free radicals that damage DNA.

Processed meats-those preserved by smoking, curing, salting, or preservatives-have been convincingly linked to an increased risk for colorectal cancer, with $18 \%$ increased risk for each $50 \mathrm{~g}$ consumed per day. ${ }^{44}$

Strategies to recommend include:

- AICR recommends limiting red meat (beef, lamb, and pork) to no more than $18 \mathrm{oz}$ (cooked weight) per week and avoiding processed meat as much as possible.

- Substituting legumes for some or all of the red and processed meat in dishes adds fiber and plant compounds; replacing some meatbased dishes with fish conforms to general nutrition guidelines.

- Increasing vegetable portions and reducing excessive meat portions work together.
Consume alcohol in moderation, if at all

In moderation, alcohol reduces insulin resistance and risk for type 2 diabetes. However, alcohol in excess increases the risk for diabetes and for colon cancer in men, pre- and postmenopausal breast cancer, and mouth and throat cancers. It may also increase risks for colon cancer in women and for liver cancer. ${ }^{18,33}$ For those who chose to drink alcohol, recommendations from AICR and ACS match those of ADA: if alcohol is consumed at all, limit alcoholic drinks to two daily for men or one daily for women.

Get daily physical activity and limit sedentary time

Regular physical activity not only reduces the risk for and helps control type 2 diabetes and cardiovascular disease, but also is linked to lower risks for cancer, especially colorectal, endometrial, and postmenopausal breast cancers. Recommendations to reduce cancer risk encourage a minimum of 30 minutes of moderate activity daily, with benefits potentially increasing by advancing to 60 minutes of moderate or 30 minutes of vigorous activity daily. ${ }^{18,33}$

Emphasizing physical activity as a cancer-protective action may help to establish a view of daily physical activity as a positive step with direct health benefits rather than as an activity associated only with weight control. Although physical activity does promote maintenance of a healthy weight, it can also reduce insulin resistance and circulating levels of IGF-1 and estrogen even without weight loss..$^{34,36,45}$

\section{A Paradigm Change}

Reframing type 2 diabetes and prediabetes as a metabolic environment conducive to cardiovascular disease and cancer development supports messages about the importance of making lifestyle changes. Educating people about eating and lifestyle choices with multiple health benefits provides important support for their overall health. 


\section{References}

${ }^{1}$ Jiang Y, Ben Q, Shen H, Lu W, Zhang Y, Zhu J: Diabetes mellitus and incidence and mortality of colorectal cancer: a systematic review and meta-analysis of cohort studies. Eur J Epidemiol 26:863-876, 2011

${ }^{2}$ Larsson SC, Mantzoros CS, Wolk A: Diabetes mellitus and risk of breast cancer: a meta-analysis. Int J Cancer 121:856-862, 2007

${ }^{3}$ Ben Q, Xu M, Ning X, Liu J, Hong S, Huang W, Zhang H, Li Z: Diabetes mellitus and risk of pancreatic cancer: a meta-analysis of cohort studies. Eur J Cancer 47:1928-1937, 2011

${ }^{4}$ Wang C, Wang X, Gong G, Ben Q, Qiu W, Chen Y, Li G, Wang L: Increased risk of hepatocellular carcinoma in patients with diabetes mellitus: a systematic review and meta-analysis of cohort studies. Int J Cancer 130:1639-1648, 2012

${ }^{5}$ Friberg E, Orsini N, Mantzoros CS, Wolk A: Diabetes mellitus and risk of endometrial cancer: a meta-analysis. Diabetologia 50:1365-1374, 2007

${ }^{6}$ Larsson SC, Orsini N, Brismar K, Wolk A: Diabetes mellitus and risk of bladder cancer: a meta-analysis. Diabetologia 49:2819-2823, 2006

${ }^{7}$ Mitri J, Castillo J, Pittas AG: Diabetes and risk of Non-Hodgkin's lymphoma: a metaanalysis of observational studies. Diabetes Care 31:2391-2397, 2008

${ }^{8}$ Kasper JS, Giovannucci E: A meta-analysis of diabetes mellitus and the risk of prostate cancer. Cancer Epidemiol Biomarkers Prev 15:2056-2062, 2006

${ }^{9}$ Snyder CF, Stein KB, Barone BB, Peairs KS, Yah HC, Derr RL, Wolff AC, Carducci MA, Brancati FL: Does pre-existing diabetes affect prostate cancer prognosis? A systematic review. Prostate Cancer Prostatic Dis 13:58-64, 2010

${ }^{10}$ Bensimon L, Yin H, Suissa S, Pollak MN, Azoulay L: Type 2 diabetes and the risk of mortality among patients with prostate cancer. Cancer Causes Control 25:329-338, 2014

${ }^{11}$ Renehan AG, Yeh HC, Johnson JA, Wild $\mathrm{SH}$, Gale EA, Moller H: Diabetes and cancer (2): evaluating the impact of diabetes on mortality in patients with cancer. Diabetologia 55:1619-1632, 2012

${ }^{12}$ Yeh HC, Platz EA, Wang NY, Visvanathan K, Helzlsouer KJ, Brancati FL: A prospective study of the associations between treated diabetes and cancer outcomes. Diabetes Care 35:113-118, 2012

${ }^{13}$ Barone BB, Yeh HC, Snyder CF, Peairs KS, Stein KB, Derr RL, Wolff AC, Brancati FL: Long-term all-cause mortality in cancer patients with preexisting diabetes mellitus: a systematic review and meta-analysis. JAMA 300:2754-2764, 2008

${ }^{14}$ Handelsman Y, Leroith D, Bloomgarden ZT, Dagogo-Jack S, Einhorn D, Garber
AJ, Grunberger G, Harrell RM, Gagel RF, Lebovitz HE, McGill JB, Hennekens CH: Diabetes and cancer: an AACE/ACE consensus statement. Endocr Pract 19:675-693, 2013

${ }^{15}$ Franciosi M, Lucisano G, Lapice E, Strippoli GF, Pellegrini F, Nicolucci A: Metformin therapy and risk of cancer in patients with type 2 diabetes: systematic review. PLoS One 8:e71583, 2013

${ }^{16}$ Shikata K, Ninomiya T, Kiyohara Y: Diabetes mellitus and cancer risk: review of the epidemiological evidence. Cancer Sci 104:9-14, 2013

${ }^{17}$ Giovannucci E, Harlan DM, Archer MC, Bergenstal RM, Gapstur SM, Habel LA, Pollak M, Regensteiner JG, Yee D: Diabetes and cancer: a consensus report. CA Cancer J Clin 60:207-221, 2010

${ }^{18}$ World Cancer Research Fund, American Institute for Cancer Research: Food, Nutrition, Physical Activity and the Prevention of Cancer: A Global Perspective. Washington, D.C., American Institute for Cancer Research, 2007

${ }^{19}$ Gallagher EJ, LeRoith D: The proliferating role of insulin and insulin-like growth factors in cancer. Trends Endocrinol Metab 21:610-618, 2010

${ }^{20}$ Vigneri P, Frasca F, Sciacca L, Pandini G, Vigneri R: Diabetes and cancer. Endocr Relat Cancer 16:1103-1123, 2009

${ }^{21}$ Becker S, Dossus L, Kaaks R: Obesity related hyperinsulinaemia and hyperglycaemia and cancer development. Arch Physiol Biochem 115:86-96, 2009

${ }^{22}$ Kaaks R, Johnson T, Tikk K, Disorn Sookthai D, Tjønneland A, Roswall N, Overvad K, Clavel-Chapelon F, BoutronRuault M-C, Dossus L, Rinaldi S, Romieu I, Boeing H, Schütze M, Trichopoulou A, Lagiou P, Trichopoulos D, Palli D, Grioni S, Tumino R, Sacerdote C, Panico S, Buckland G, Argüelles M, Sánchez M-J, Amiano P, Chirlaque M-D, Ardanaz E, Bueno-deMesquita HB, van Gils CH, Peeters PH, Andersson A, Sund M, Weiderpass E, Gram IT, Lund E, Khaw K-T, Wareham N, Key TJ, Travis RC, Merritt MA, Gunter MJ, Riboli E, Lukanova A: Insulin-like growth factor 1 and risk of breast cancer by age and hormone receptor status: a prospective study within the EPIC cohort. Int J Cancer 134:2683-2690, 2014

${ }^{23}$ Price AJ, Allen NE, Appleby PN, Crowe FL, Travis RC, Tipper SJ, Overvad K, Grønbæk H, Tjønneland A, Johnsen NF, Rinaldi S, Kaaks R, Lukanova A, Boeing $\mathrm{H}$, Aleksandrova K, Trichopoulou A, Trichopoulos D, Andarakis G, Palli D, Krogh V, Tumino R, Sacerdote C, Bueno-deMesquita HB, Argüelles MV, Sánchez M-J, Chirlaque M-D, Barricarte A, Larrañaga N, González CA, Stattin P, Johansson M, Khaw K-T, Wareham N, Gunter M, Riboli E, Key $\mathrm{T}$ : Insulin-like growth factor-1 concentration and risk of prostate cancer: results from the European Prospective Investigation into
Cancer and Nutrition. Cancer Epidemiol Biomarkers Prev 21:1531-1541, 2012

${ }^{24}$ Wu Y, Antony S, Meitzler JL, Doroshow $\mathrm{JH}$ : Molecular mechanisms underlying chronic inflammation-associated cancers. Cancer Lett 345:164-173, 2014

${ }^{25}$ Guo YZ, Pan L, Du CJ, Ren DQ, Xie XM: Association between $\mathrm{C}$-reactive protein and risk of cancer: a meta-analysis of prospective cohort studies. Asian Pac J Cancer Prev 14:243-248, 2013

${ }^{26}$ Allin KH, Nordestgaard BG: Elevated $\mathrm{C}$-reactive protein in the diagnosis, prognosis, and cause of cancer. Crit Rev Clin Lab Sci 48:155-170, 2011

${ }^{27}$ Guo S, Liu M, Wang G, Torroella-Kouri M, Gonzalez-Perez RR: Oncogenic role and therapeutic target of leptin signaling in breast cancer and cancer stem cells. Biochim Biophys Acta 1825:207-222, 2012

${ }^{28}$ Pais R, Silaghi H, Silaghi AC, Rusu ML, Dumitrascu DL: Metabolic syndrome and risk of subsequent colorectal cancer. World J Gastroenterol 15:5141-5148, 2009

${ }^{29}$ Stattin P, Bjor O, Ferrari P, Lukanova A, Lenner P, Lindahl B, Hallmans G, Kaaks R: Prospective study of hyperglycemia and cancer risk. Diabetes Care 30:561-567, 2007

${ }^{30}$ Joshu CE, Prizment AE, Dluzniewski PJ, Menke A, Folsom AR, Coresh J, Yeh HC, Brancati FL, Platz EA, Selvin E: Glycated hemoglobin and cancer incidence and mortality in the Atherosclerosis in Communities (ARIC) Study, 1990-2006. Int J Cancer 131:1667-1677, 2012

${ }^{31}$ Grote VA, Rohrmann S, Nieters A, Dossus L, Tjønneland A, Halkjær J, Overvad K, Fagherazzi G, Boutron-Ruault MC, Morois S, Teucher B, Becker S, Sluik D, Boeing H, Trichopoulou A, Lagiou P, Trichopoulos D, Palli D, Pala V, Tumino R, Vineis P, Panico $S$, Rodríguez L, Duell EJ, Molina-Montes E, Dorronsoro M, Huerta JM, Ardanaz E, Jeurnink SM, Beulens JW, Peeters PH, Sund M, Ye W, Lindkvist B, Johansen D, Khaw KT, Wareham N, Allen N, Crowe F, Jenab M, Romieu I, Michaud DS, Riboli E, Romaguera D, Bueno-de-Mesquita HB, Kaaks R: Diabetes mellitus, glycated haemoglobin and C-peptide levels in relation to pancreatic cancer risk: a study within the European Prospective Investigation into Cancer and Nutrition (EPIC) cohort. Diabetologia 54:3037-3046, 2011

${ }^{32}$ Johnson JA, Bowker SL: Intensive glycaemic control and cancer risk in type 2 diabetes: a meta-analysis of major trials. Diabetologia 54:25-31, 2011

${ }^{33}$ Kushi LH, Doyle C, McCullough M, Rock CL, Demark-Wahnefried W, Bandera EV, Gapstur S, Patel AV, Andrews K, Gansler T; American Cancer Society 2010 Nutrition and Physical Activity Guidelines Advisory Committee: American Cancer Society guidelines on nutrition and physical activity for cancer prevention: reducing the risk of cancer with healthy food choices and physical activity. CA Cancer J Clin 62:30-67, 2012 


\section{Nutrition FYI}

\begin{abstract}
${ }^{34}$ American Diabetes Association: Standards of medical care in diabetes-2014. Diabetes Care 37 (Suppl. 1):S14-S80, 2014
\end{abstract}

${ }^{35}$ Mason C, Foster-Schubert KE, Imayama I, Kong A, Xiao L, Bain C, Campbell KL, Wang CY, Duggan CR, Ulrich CM, Alfano CM, Blackburn GL, McTiernan A: Dietary weight loss and exercise effects on insulin resistance in postmenopausal women. Am J Prev Med 41:366-375, 2011

${ }^{36}$ Campbell KL, Foster-Schubert KE, Alfano CM, Wang CC, Wang CY, Duggan CR, Mason C, Imayama I, Kong A, Xiao L, Bain CE, Blackburn GL, Stanczyk FZ, McTiernan A: Reduced-calorie dietary weight loss, exercise, and sex hormones in postmenopausal women: randomized controlled trial. J Clin Oncol 30:2314-2326, 2012

${ }^{37}$ Dow CA, Thomson CA, Flatt SW, Sherwood NE, Pakiz B, Rock CL: Predictors of improvement in cardiometabolic risk factors with weight loss in women. J Am Heart Assoc 2:e000152, 2013

${ }^{38}$ Norat T, Chan D, Lau R, Aune D, Vieira R: The Associations Between Food, Nutrition and Physical Activity and the Risk of
Colorectal Cancer. WCRF/AICR Systematic Literature Review Continuous Update Project Report. London, World Cancer Research Fund and American Institute for Cancer Research, 2010

${ }^{39}$ Perez-Escamilla R, Obbagy JE, Altman JM, Essery EV, McGrane MM, Wong YP, Spahn JM, Williams CL: Dietary energy density and body weight in adults and children: a systematic review. J Acad Nutr Diet 112:671-684, 2012

${ }^{40}$ Rolls BJ, Drewnowski A, Ledikwe JH: Changing the energy density of the diet as a strategy for weight management. J Am Diet Assoc 105 (5 Suppl. 1):S98-S103, 2005

${ }^{41}$ Blatt AD, Roe LS, Rolls BJ: Hidden vegetables: an effective strategy to reduce energy intake and increase vegetable intake in adults. Am J Clin Nutr 93:756-763, 2011

${ }^{42}$ Ledikwe JH, Blanck HM, Khan LK, Serdula MK, Seymour JD, Tohill BC, Rolls BJ: Lowenergy-density diets are associated with high diet quality in adults in the United States. $J$ Am Diet Assoc 106:1172-1180, 2006

${ }^{43}$ Dong JY, He K, Wang P, Qin LQ: Dietary fiber intake and risk of breast cancer: a meta- analysis of prospective cohort studies. Am J Clin Nutr 94:900-905, 2011

${ }^{44}$ Chan DS, Lau R, Aune D, Vieira R, Greenwood DC, Kampman E, Norat T: Red and processed meat and colorectal cancer incidence: meta-analysis of prospective studies. PLoS One 6:e20456, 2011

${ }^{45}$ Wu Y, Zhang D, Kang S: Physical activity and risk of breast cancer: a meta-analysis of prospective studies. Breast Cancer Res Treat 137:869-882, 2013

Karen K. Collins, MS, RDN, CDN, is a consultant based in Bemus, N.Y., who serves as a nutrition advisor to the American Institute for Cancer Research.

\section{(C) 2014 by the American Diabetes}

Association. Readers may use this article as long as the work is properly cited, the use is educational and not for profit, and the work is not altered. See http://creativecommons. org/licenses/by-nc-nd/3.0 for details.

\section{BMJ Open Diabetes Research \& Care}

Your open access option for high-quality diabetes research

\author{
New Journal! From BMJ and the American \\ Diabetes Association. Content includes \\ original medical research from all disciplines \\ and therapeutic areas of diabetes research, \\ management and treatment.
}
- Edited by leading experts in diabetes and endocrinology

- Online-only format-allows for continuous updates

Learn more and submit your research at diabetesrc.bmj.com

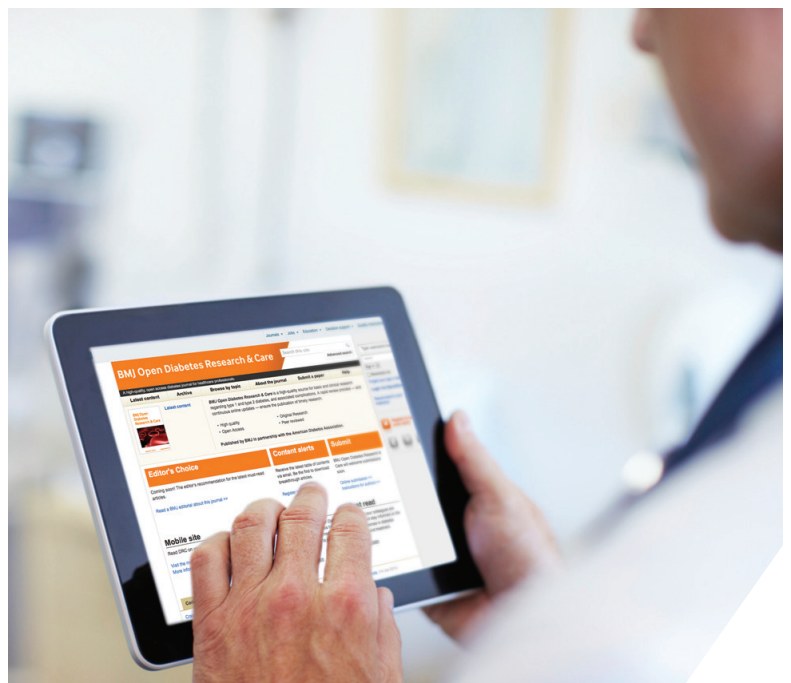

- Rigorous peer review-only original research accepted

- doc2doc diabetes forum-join the conversation! 